\title{
Constraints in English Speaking: A Case Study on Students of Teacher Training and Education Faculty, Riau University, Indonesia
}

\author{
Mahdum \\ English Department, Teacher Training and Education Faculty \\ Universitas Riau, Kampus Panam Pekanbaru, Riau, Indonesia \\ mahdum1211@gmail.com
}

\begin{abstract}
Recognize of the importance of English speaking ability, Teacher Training and Education Faculty (FKIP) - Riau University has implemented English as a compulsory subject for all students since 2014. The focus of this subject is to improve students' oral communication. However, it is not easy in obtaining good speaking ability. This research aims to descriptively identify the constraints faced by students in obtaining good speaking ability as well as to look for the solutions. The formulation of the problems to be addressed are: (1) What are the constraints faced by students in speaking? (2) What kinds of learning materials do the students want in order to they are able to improve their speaking ability? and (3) What kinds of teaching models should be used by the lecturers so that the students feel motivated to learn? This research was conducted during odd semester of academic year 2014-2015. In total 48 students from 16 available departments at Teacher Training and Education Faculty of Riau University were randomly chosen as the sample. The instrument used was a semi-structured interview, observation and documents observation. All the interviews were tape-recorded and transcribed word by word. The finding of the research shows that limited number of vocabulary, difficulties to understand grammar rules, do not have enough chances to speak English during the class, and poor environment for spoken communication in English outside class seem contributed to the students' insufficient ability in speaking.
\end{abstract}

Keywords: Speaking ability; Learning materials; Constraints; Semi-structured interview

\section{Introduction}

English has become an important and a global language nowadays. It is spoken and learnt even in those countries where it is not a native's language. English also plays a major role in many sectors such as: education, advanced studies, economic, medicine, business, technology, and etc [1]. As a result, English is being taught and learned around the world as a second language today, including in Indonesia [2].

The ability to speak English for a university graduate, including graduates of FKIP Riau University, Indonesia is something that is absolutely necessary. This ability may also give additional value for them when they are looking for a job later on. However, in order to become a well-rounded communicator, the students need to be proficient in each of the four language skills: listening, speaking, reading and writing. The capacity to express thoughts, opinions and feelings, in the form of words put together in a meaningful way, provides them the joyfull of sharing ideas with others. The ability to speak skilfully also provides the students with several distinct advantages. In reality, however, we cannot close our eyes to see that many students of FKIP Riau University still have insufficient ability in speaking. 
Addressing the lack of competitiveness of the students, FKIP Riau University as one of the educational institutions, has been trying hard to improve the abilities and the competitiveness of the students. One of the efforts done is to put English as a compulsory subject for all students of FKIP Riau University. This is implemented in the new curriculum which is called Curriculum 2014. Given the English Subject, students are expected to be familiar with the use of English as a tool of communication. In fact, many students are good in structure but they cannot use their grammar knowledge to communicate appropriately. The fact shows that during teaching and learning process many students can read and write well in English, but they are poor at speaking and listening. Many students love to speak English, but they make a lot of grammatical mistakes, while some others are too afraid to talk in class. They are shy and lack of confidence. The implementation of Curriculum 2014 is started in odd semester 2014. According to this curriculum English should be taught to all of the first year students of FKIP Riau University. At the previous curriculum, however, some of departments available at FKIP Riau University also offer English subject, but the implementation of teaching and learning process as well as the instructional materials have not been implemented in a coordinated manner. Even, at some departments, English is taught by the lecturers who are considered "know" English because the ever studied abroad.

In the classroom, many students feel frustrated as they find that speaking in a foreign language is a complex matter. It is because speaking involves many factors. Harmer in [3] says that the ability to speak fluently presupposes not only knowledge of language features, but also the ability to process information and language 'on the spot'. Burns in [4] also says that speaking is a highly complex and dynamic skill that involves the use of several simultaneous processes - cognitive, physical and socio-cultural - and a speaker's knowledge and skills have to be activated rapidly in real-time. Therefore speaking skill needs to be taught explicitly in the classroom.

This paper is aimed to find out (1) the constraints faced by students in speaking; (2) learning materials preferred by the students so that they are able to improve their speaking skill; and (3) teaching models should be used by the lecturers so that the students feel motivated to learn. So, research questions to be answered are: (1) What are the constraints faced by students in speaking? (2) What kinds of learning materials do the students want so that they are able to improve their speaking skill? and (3) What kinds of teaching models should be used by the lecturers so that the students feel motivated to learn?

In summary, the contributions of this research are given as follows:

a. Try to present concise and precise additional knowledge and information about the teaching and learning of English, especially in teaching and learning speaking.

b. Provide several alternative ways to improve students' speaking ability.

c. Provide references for the next researchers at the same field.

The remaining structure of this paper is organized as follows: Section 2 presents brief review of related theories. Section 3 gives the description of research methodology. Section 4 presents research findings. Finally, section 5 gives conclusion and recommendations.

\section{Rudimentary}

Language is a tool for communication [5]. Everybody communicates each other to express ideas, and to know others' ideas as well. Communication takes place, where there is a speech. Without speech we cannot communicate with one another. Everybody communicates in a variety of situations: at home, at work, in the market, in the office, or in their community. In order to communicate well with one another, everybody is supposed to speak correctly and effectively. Any gap in communication may cause 
misunderstandings and problems [6]. That's why the importance of speaking skill is enormous for everybody, including the learners of any language.

According to Gert and Hans in [7], speaking is speech or utterances with the purpose of having intention to be recognized by speaker and the receiver processes the statements in order to recognize their intentions. Brown and Yule in [8] state that speaking is depending on the complexity of the information to be communicated; however, the speaker sometimes finds it difficult to clarify what they want to say. Rebecca in [9] states that speaking is the first mode in which children acquire language, it is part of the daily involvement of most people with language activities, and it is the prime motor of language change. It also provides main data for understanding bilingualism and language contact.

An effective speaker can gain the attention of the audience and hold it till the completion of his message. Speaking skill is important for career success, but certainly not limited to one's professional aspirations. Speaking skill can also enhance one's personal life [10]. In the context of foreign language learning, however there is a problem which lecturers have been aware of for a long time. The lecturers say that many students are structurally competent but they cannot communicate appropriately. In order to overcome this problem the lecturers should focuses on the processes involved in the conversational interaction of the students. In other words, the lecturers should conduct such activities in the class which enable the students to be 'able to use the language appropriate to given social context'. To enhance the students' speaking ability, the lecturer should adopt and adapt such kinds of teaching techniques which provide an opportunity to the students to speak. These activities are intended to enhance their communicative competence. Nowadays, some different methods, approaches, and techniques are employed in order to encourage students to speak English. According to Qureshi in [10], the lecturers may provide the learners with as many opportunities as possible to learn different linguistic forms, their meanings and their functions in different social contexts.

Burns in [4] argues that teaching model implies by the lecturers need to be conceptualized and supported learning opportunities for developing various components of speaking competence. It is important that the lecturers guide the students systematically. Th lecturers may also introduce integrated and sequenced activities that allow students aware of the knowledge, skills and strategies needed for various types of interaction and discourse. Moreover, the lecturers should also guide the students on specific aspects of the language, such as pronunciation features, or the students may need support in relation to affective factors, such as anxiety, nervousness and embarrassment about speaking in English language.

Brown in [11] proposes some principles for designing speaking techniques as follow: (1) Use techniques that cover the spectrum of learner needs, from language-based focus on accuracy to message-based focus on interaction, meaning, and fluency; (2) Provide intrinsically motivating techniques; (3) Encourage the use of authentic language in meaningful contexts; (4) Provide appropriate feedback and correction; (5) Capitalize on the natural link between speaking and listening; (6) Give students opportunities to initiate oral communication; (7) Encourage the development of speaking strategies. The above techniques suggest that English lecturers have bigger responsibility not only to teach the structure of sentences and then ask the students to speak with that grammar, but also to prepare the lesson well in order to encourage the students to speak and to be more communicative. Besides, lecturers need to create the speaking class environment, adopt and adapt many ways and encourage the students to open their mouths to speak.

During teaching and learning process happened in the classroom, many times the students fail to find suitable words to express themselves and at another side, they are afraid of making mistakes. Sometimes they make mistakes when they are speaking because they are shy and nervous. To avoid these situations, the lecturers should be able 
to provide situations that help the students speak actively and correctly. On one hand, the lecturers should try to ease students and remove their nervousness, fear and anxiety with encouraging words. According to Madsa in [12], to build a free and lighted-hearted environment the lecturers may do these efforts: (1) try to arrange the seats of my classroom in a circle or in groups with the students facing each other not in rows and lines; (2) let the students speak English sitting in their seats not standing; (3) at first stage, teachers allow the students to play their tape recording they have prepared for a certain topic beforehand; (4) try to divide the students into pairs and groups according to the different topics and (5) let the students prepare their "opinion", and then have a group leader to deliver the opinion.

It is essential to try to build an atmosphere where the students no longer feel shy, and will voluntarily raise their hands to ask a question or freely voice their own opinions. After students finish their speaking in class, lecturers should also encourage the students and let them feel that they have made some progress with a sense of their fulfillment. According to Madsa in [12] the lecturers should try to do these: (1) Be firm in a gentle way and give them praise whenever they are doing anything close to a good job; (2) Be sincere and look for opportunities to find them doing something right. Never get frustrated, angry and impatient; (3) Be a nice, sensitive, and approachable person at all times; (4) Treat them with kindness and respect. Smile a lot and value their opinions; and (5) Allow the students to be themselves rather than expecting them to conform to the lecturers' preconceived ideas about how they should behave. Of course the lecturers should point out some apparent mistakes in their speaking, for example, the incorrect words in pronunciation or some serious mistakes in grammar after they finish their speech.

Lecturers play an important role in making the class lively and active by their guide and arrangement. Students' initiatives should be encouraged and respected, but it does not mean there is no guide or assessment on the part of the lecturers. After all, the guidance and help of the lecturers make their job inevitable in the classroom and education. Lecturers should invent more ways to let students practice. This will arouse their interest to speak and help them more easily to master this skill. Richards [13] argued about the ability that lecturers should possess, among others: (1) The ability to provide good language models; (2) The ability to maintain the use of the target language in the classroom; and (3) the ability to provide examples of words with grammatically correct structure; and (4) the ability to provide an accurate explanation. Furthermore, it is suggested that language skills not only to contribute to teaching skills, but also increase the confidence in teaching.

\section{Proposed Method}

This is a descriptive study using a mixed-method that adopted both quantitative and qualitative methods. Mixed-methods is one in which the researcher use several strategies of investigation that engage with collecting data either concurrently or sequentially to best understand the research problem [14]. The participants of this research were 48 students from different available Departments at FKIP Riau University. Cluster random sampling technique was used to choose these students. All of these students were the third semester students who had taken English Subject. In order to investigate the perceived the constraints faced by the students in speaking, semi-structured interview were conducted with all the participants. This semi-structured interview provided the students with opportunities to talk by using their own words. Moreover, this also aimed for "concrete and complex illustrations" [15]. Besides, observation and documents observation are also used to support the result of the interview.

Each interviewee was asked to describe their English speaking experience as English language learners during taking English subject. The interview focused on the constraints 
with speaking in English that they had experienced during taking the course as well as their expectation about teaching materials and teaching method they preferred. Probing questions was also used to gain a fuller understanding of the issues. All the interviews were tape-recorded and transcribed word by word. In keeping with a tradition in qualitative research, the transcripts of the interviews were read, re-read and annotated with comments and specific descriptive phrases, a process that Merriam in [16] calls "open coding".

\section{Result and Discussion}

This section presents the findings based on the interviews.

\subsection{Constraints Faced by the Students}

Student's ability to communicate can be reflected in their knowledge and ability to implement that knowledge in the use of communicative and contextual language. This is in accordance with the opinion of Gan in [17]. Gaining this ability, however, is not easy. The following will describe the constraints faced by students in communication:

\section{a. Limited Number of Vocabulary}

From the interviews revealed that limited number vocabulary is a common concern among students. Students say that when they are speaking, there are many things that they want to say, but they do not have enough vocabulary to express what is in their minds whether in asking questions or in answering the lecturers' questions. As a result, they preferred to be a good listener only and pretended not to notice when lecturers asked questions. Almost all the students agreed with the opinion that this vocabulary problem was the major reason why they were sometimes could not express themselves clearly and appropriately. They also believed that this contributed directly to a lack of fluency in their speech. During the interview, they all emphasized a need to further expand their vocabulary

\section{b. Hard to Apply Grammar Rules when Speaking}

A number of students say that they have difficulties to understand grammar rules. Sometimes, they felt already knew the rules in such a simple grammar, sentence patterns, tenses or subject - verb agreement, and so forth. But when they were speaking, the students were failing to pay attention to these rules and ended up making mistakes. The constraints faced by students also associated with different linguistic problems (problems of grammar, lexical and phonological).

\section{c. Not Perfect Pronunciation andIntonation}

Some students mentioned that they had to speak carefully to focus on how to pronounce certain words accurately, especially words that are less common. Many times, they were not able to pronounce words or sentences correctly. Other students said they had troubles in pronouncing some of the vocals or certain consonants that do not exist in Indonesian, for example, pronounce 'a' and 'ae'. There were also students who mentioned the difficulties in articulation. These can make students felt reluctant to speak. Some of the students in this study also had problems in pronouncing words that had both American and British English pronunciation.

\section{d. Lack of Opportunities to Speak in Class}

Many students said that they do not have enough chances to speak English during the class. Talking-time is dominated by the lecturer. There were even some students who said 
that they never spoke even during lectures occurred. They never asked directly by the lecturer nor ever intended to speak. Generally, students who had a chance to speak were a student who got a direct question from lecturer or students who were assigned to convey the results of group discussions.

\section{e. Less Support of Environment Outside the Classroom}

Students said that the atmosphere and the campus environment were not supportive in improving their English speaking ability. Although all students knew that there is a saying in English that says practice makes perfect, but it was still only an expression. Many students did not realize the importance of exercise to use English orally as one of the application forms of language knowledge they already possess. There were students who said they had been trying to speak English outside the classroom, but they felt embarrassed. Sometimes they felt strange when they tried to speak English. However, the use of Indonesian and regional languages still dominated the communication activities at campus.

\subsection{Students' Desired Instructional Materials}

Some information related to instructional materials prepared by lecturers also gained through the interview and observation. It was found out that instructional materials prepared by lecturers in various departments were not the same. Some lecturers prepared the materials determined by faculty and some others prepared the materials based on the request from the head of the departments. Some of the instructional materials prepared by the lectures were associated with the theory of language teaching and learning; some were focused on grammar; some were paid more attention to increase knowledge of the language system; while some others were aimed to improve the ability of students to use the language in real communication. Unclear focus on the curriculum to be achieved in each department is also a factor that makes instructional materials presented by the lecturers are different. Things like this seem fail to meet the wishes of most of students to improve their English communication skill. As a result, they are not able to use English fluently and confidently. In the future, however, through the application of Curriculum 2014 FKIP Riau University will prepare the same instructional materials for students of all departments available at FKIP Riau University.

Based on the constraints faced by students, it can be formulated that students' desired instructional materials are materials that can help them improve their vocabulary, grammar, as well as their pronunciation and intonation. These findings are in accordance with the opinion of Fulcher in [18], who says that anyone who wishes to speak a second language has to learn grammar, vocabulary, and voice controls. Due to the lack of a clear pronunciation, second language learners tend to be more vulnerable to criticism and negative evaluations than learning other subjects because of the possibility of making a mistake in using language that is much larger [19].

\subsection{The Teaching Models that Should be Used by the Lecturers}

Based on interviews, some information about the desired teaching models should be used by the lecturers were also found. Most students preferred to have teaching models that allow them to create interactive communication between students and lecturers or vice versa, and interactive communication among students. According to the students, by applying these kinds of models they would have more opportunity to speak in class. In traditional way of teaching, usually the lecturers dominate the conversation in class. In the future, however, this paradigm should be changed. The lecturers should move from traditional ways of teaching to innovative teaching models; from lecturing activity to process-oriented activities; from teacher-centered activities to student-centered activities. 


\subsection{Discussion}

This study was designed to find out constraints faced by the students of FKIP Riau University in English speaking, as well as to offer the solutions. The finding of this research lead to agree with Fulcher's argument that says second language speaking is complex [17]. To be a good speaker, the students need to have sufficient knowledge of the language feature, enough grammar and vocabulary of the language, and understand how stretches of connected speech are organized. In addition, the students also have to know about communication strategy. Johnson in [20] describes speaking as a "combinatorial skill" that "involves doing various things at the same time". Burns in [4] proposed three components of second language speaking competence: knowledge of language and discourse, core speaking skills, and communication and discourse strategies. Learning to speak in a second language involves increasing the ability to use these components in order to produce spoken language in a fluent, accurate and socially appropriate way, within the constraints of a speaker's cognitive processing. Knowledge of language and discourse requires mastering the sound patterns of the language, knowing the grammar and vocabulary of the language and understanding how stretches of connected speech organized. Core Speaking Skills means developing the ability to process speech quickly to increase fluency. It also involves being able to negotiate speech monitoring understanding, as well as managing the flow of speech. Communication Strategies, involves developing cognitive strategies, metacognitive strategies and interaction strategies.

Dealing with the teaching models used by the lecturers, based on the finding of the research it can be said that the students prefer to have learning models that allow them to create interactive communication between students and lecturers or vice versa, and interactive communication among students. To realize the students' need, the lecturers should move from a product-oriented to one that is more process-oriented and learnercentered. By applying process-oriented and learner-centered the lecturers may create the conditions under which learners may acquire the speaking skills they need in and outside the classroom. In relation to the activities in order to develop the speaking ability, there are many ways to promote oral skills in the classroom. Discussions, speeches, role-play, language games, among others, are the most typical speaking activities. However, discussions are probably the most commonly activity can be applied in class. The lecturers may give the students a selected topic from reading text or a videotape, then the students sit in pairs or small group to discuss in order to come up with a solution. Students will be more involved with and motivated to participate in discussions if they choose the topics in relation to their likes and dislikes. According to Fulcher [18], the lecturers can arrange the students to engage in small discussions at appropriate moments. One of the advantages of discussion in small groups is that the activities allow students to use English without feeling shy to speak in front of all her friends in the class.

Discussions in small groups can also make students become less dependent on the lecturers and able to build up their confidence in using the English language for a meaningful communication. This is in accordance with the opinion of Liu and Littlewood in [21]. Student-centered learning activities will meets the desire of students to actively participate in learning process and will be reflected in the activities they do during the discussions. In short, lecturers should be able to create conditions in which students can acquire the language skills they need inside and outside the classroom. In summary, it can be said that speaking is a complex process that involves the students to construct and deliver a message using the correct grammar, pronunciation, stress and intonation. It also involves interaction. At the same time the students must be able to respond what the listeners say. At the same time, they need to be accurate and fluent enough for the listeners to understand. To be able to do all of these mentioned, students need lots of practices, encouragement and corrections as well as guidance from the lecturers. 


\section{Conclusion and Recommendations}

This paper has successfully found out constraints faced by students of FKIP - Riau University in English speaking as well as offer solutions that can be applied by the lecturers and the students. During teaching and learning process, the lecturers should not just presenting the teaching materials and then ask the students to speak, but must prepare a proper teaching materials in order to encourage the students to speak. The lecturers should also be more innovative to adopt and adapt a variety of approaches in teaching speaking. In addition, the lecturers together with decision makers at FKIP Riau University need to create a learning environment that facilitates students to develop their speaking ability.

It is recommended that FKIP Riau University to facilitate adequate learning environment that may allow the students to learn English on campus. The faculty may provide extra-curricular activities, for example is by setting an English-day at least one day in a month. During the English Day, everybody in campus should speak English. English-day also provides greater opportunities for students to learn and practice their English in a pleasant situation and at the same time help the student to develop their ability to communicate in a wider range. As reflected in the comments of students in this study, it was revealed that the majority of students seldom use English outside the classroom. Providing of adequate language practice such as English-day will be very important for the development of speaking skills of students. Other students say that the faculty should provide what they called English Zones. The English Zone is an area where all the students who are doing activities in this area, should speak English. Some English Zone can be provided at campus. In addition, the students also dreamed the availability of a special room somewhere at campus. In that room the students can watch English TV programs during their leisure time. They may watch various English programs: news, film, music, sport, etc. In this way they can imitate the style of speech of others, improve the ability to hear, and know the culture of others. Further, this can cause motivation in learning English.

\section{Acknowledgement}

This work is supported by University of Riau, Research Grant no 1873/UN19.5.1.1.5/TU/2015 from the Dean of Faculty of Teachers Training and Education (FKIP) - Riau University

\section{References}

[1] D. Graddol, "The future of English", London: The British Council, (1997).

[2] A. Lauder, "The status and function of English in Indonesia: A review of key factors", Makara HubsAsia, vol. 8, no. 3, (2010).

[3] J. Harmer, "The practice of English Language Teaching”, Edinburgh: Pearson Education Limited, (2001).

[4] A. Burns, "Teaching speaking: A holistic approach”, New York: Cambridge University Press, (2012).

[5] D. L. Everett, "Language: The cultural tool", Vintage, (2012).

[6] A. Mauranen, "Signaling and preventing misunderstanding in English as lingua franca communication", (2006).

[7] R. Gert and S. Hans, "Handbook of Communication Competence", Germany, (2008).

[8] G. Brown and G. Yule, "Teaching the spoken Language”, Cambridge University Press, (1999).

[9] H. Rebecca, "Spoken English, TESOL, and applied Linguistics: Challenges for Theory and Practice", Great Britain: CPI Antony Rowe, (2006).

[10] I. A. Qureshi, "The Importance of Speaking Skills for EFL Learners", https://upload.wikimedia.org/wikipedia/commons/e/e3/Speaking_Skills.pdf. retrieved on July 7, 2015.

[11] H. D. Brown, "Teaching by Principles: An Interactive Approach to Language Pedagogy", New York: Addison Wesley Longman, Inc, (2001).

[12] T. Madsa, "Motivating Students' Speaking Skill through Simulation In English For Specific Purposes", University International Converence, Rajamangala University of Technology Srivijaya, (2012); Songkhla, Thailand. 
[13] J. W. Creswell, "Research Design: Qualitative, Quantitative, and mixed methods approaches (3rd Eds.)", London: SAGE Publications, Inc, (2009).

[14] J. C. Richards, "Competence and performance in language teaching", RELC Journal, vol. 41, no. 2, (2010), pp. 101-122.

[15] H. F. Wolcott, "Transforming Qualitative Data: Description, Analysis, and Interpretation", Thousand Oaks, CA: Sage, (1994).

[16] S. B. Merriam, "Qualitative research: A guide to design implementation", San Francisco, CA: JosseyBass, (2009).

[17] Z. Gan, "Understanding L2 Speaking Problems: Implications for ESL Curriculum Development In A Teacher Training Institution In Hong Kong”, Australian Journal of Teacher Education, vol. 37, no. 1, (2012), pp. 42-56.

[18] G. Fulcher, "Testing second language speaking”, Pearson Education Limited, (2003).

[19] A. Tsui, "Classroom interaction", In R Carter and D. Nunan (eds.), The Cambridge Guide to Teaching English to Speakers of Other Languages, Cambridge: Cambridge University Press, (2001).

[20] K. Johnson, "Language teaching and skill learning", Oxford: Blackwell, (1996).

[21] N. F. Liu and W. Littlewood, "Why do many students appear reluctant to participate in classroom learning discourse?", System, vol. 25, no. 3, (1997), pp. 371-384. 
International Journal of $u-$ and e- Service, Science and Technology Vol.10, No.4 (2017) 